\title{
Storing and Transporting Hazardous Material, Logistics Strategies for Moroccan Companies
}

\author{
Abdellatif Soussi ${ }^{* 1,2}$, Dounia Bouchta ${ }^{1}$, Roberto Sacile ${ }^{2}$, Chiara Bersani $^{2}$, Hamid Seghiouer ${ }^{3}$, Ahmed El Amarti $^{1}$, Rachid Abouettahir ${ }^{3}$, \\ Redouan El Khamlichi ${ }^{1}$
}

${ }^{1}$ Laboratory of Materials and Interfacial Systems Faculty of Sciences, UAE Tétouan, 93000, Morocco

${ }^{2}$ Department on Informatics, Bioengineering, Robotics and Systems Engineering. University of Genova, 16145, Italy

${ }^{3}$ Laboratory MOSIL National School of Applied Sciences Tétouan, 93000, Morocco

\begin{tabular}{l} 
A R T I C L E I N F O \\
\hline Article history: \\
Received: 22 October, 2019 \\
Accepted: 16 December, 2019 \\
Online: 15 January, 2020 \\
\hline Keywords: \\
Hazardous Materials \\
Risk \\
Transport \\
Storage \\
Logistics
\end{tabular}

\begin{abstract}
A B S T R A C T
Companies manufacturing, using or transporting hazardous materials (HM) face risks at every link in their supply chain. Industrial activities related to this type of material expose not only the workers, but also the population and environment to serious risks.

Logistic management and risk management are often considered independent. However, logistics choices related to hazardous materials mix the two aspects in an inseparable way. In fact, risk management must be synchronized with the choices and logistics strategies of companies. The analysis of the risk relating to the management of these HMs, therefore, requires making methodological choices, but also using a lot of data, which are often incomplete.

The achievement of the present study was a real challenge owing to the lack of information and statistics on the use, transportation or storage of HMs in Moroccan territory.

The purpose of this study is to provide a portrait of the industrial practices surrounding the management of hazardous materials in Morocco in order to identify the determining factors, specifically those related to health, safety at work, in the logistic choices of companies as well as the different strategies that take into account the variables: storage, transport and quantity, including cost and risk factors.

In this context, and to conduct a survey on the logistic choices related to hazardous materials at our country, we have set up a questionnaire that will try to reach the largest number of Moroccan companies. This questionnaire focuses on the practices surrounding: procurement, shipping, storage, outsourcing, risk management, the influence of economic factors on the management of hazardous materials and the elements affecting specifically workers.
\end{abstract}

\section{Introduction}

The number of industrial companies producing, using, storing and, or transporting Hazardous Materials (HM) is constantly increasing worldwide due to the growth of demand in various sectors [1]. Because of their nature, these materials require special attention. HM accidents are rare events. Yet their occurrence can result in catastrophic industrial consequences. Here we can take the example of chemical accidents that are defined as the release of notable amount of toxic materials during storage, production, transportation, use and disposal of chemicals. Such accidents may

*Abdellatif Soussi, Email : abdellatifsoussi90@gmail.com lead to a real disaster. For instance poisoning which affects in a serious way all the people the properties and the environment $[2,4]$.

In general, risk is well defined in terms of both the likelihood of the incident and the magnitude of the loss, injury, and damage as a measure of economic loss, human injury, or environmental damage $[5,6]$. To define a risk able to manage aid decision makers in the transport of dangerous goods, it is useful to refer to a classification hierarchy of the decisional levels that may be associated with the management of that type of transport taking into account economic, environmental, and risk aspects $[7,8]$. 
The risk of transporting HM varies depending on the type of substance. Transporters of hazardous goods must be aware of how these materials are classified to ensure compliance with marking, labeling, placarding, and shipping paper requirements [9]. HMs may be classified in any of the following: explosives, gases, flammable liquids, flammable solids, oxidizing substances, poisons and infectious substances, radioactive material, corrosives, miscellaneous goods, and other regulated materials [9].

HMs transport incidents may occur at the origin or at the destination (loading and unloading) or on the route [10]. Studies have shown that the frequency of accidents during the transport of dangerous goods by road and rail has increased [11]. Most of these accidents were followed by fire, explosions and gas clouds [12,13]. As an example, statistically, there were 11,000 hazmat transport companies involving 310,000 vehicles and 1.2 million employees in China in 2015 [14].

In recent decades, several historical surveys have been published on accidents in chemical plants and in the transportation of HMs $[15,18]$. A survey of accidents that occurred during HM's road and rail transport shows that accidents frequency has increased in the 20th century, most of which are on the road [11]. Another survey was conducted on the practices of firms hazmat handling facilities, this research focused on hazmat shipments and mode of transportation and various HM and outsourced activities [19]. In [20] the authors conducted a survey covering both technical elements of HM such as the class of these materials, geographic sites covering activities, supply and shipping, various practices related to HM (loading / unloading) and organizational elements for companies using HMs (risk management, emergency preparedness, training, subcontractors). A survey of the accident situation of tankers carrying HMs was conducted in order to identify the different causes and hazard classes for HM accidents, consequences and corresponding probabilities [21].

The study of the literature shows that a multitude of models have developed to take into account different risks on different parts of the supply chain, to various activities [22-25]. Thus, decisions at the operational level (for example, a truck driver) will not be the same as those taken at the tactical level (for example, the head of the part of the company), nor even as those taken at the strategic level (for example, the management team). Yet, each can opt for the best decisions according to their own point of view, their own information and their own objectives. The purpose is to assure a vertical cooperation in order not to have these various objectives in comparison with one another on the decision-making plan. For instance, a decision taken at the operational level which improves the performance of the activities of the truck driver, could really have negative impacts on the global performance of the chain (channel).

Nowadays in Morocco the chemical materials are used in the most productive sectors including industry, agriculture, health, mining and quarrying and consumption [26]. However, the chemical industry is based, essentially, on three classes of products in this case: petroleum products, industrial chemicals and fertilizers.
The dangerous consequences of HM accidents have urged the Moroccan legislation to pay serious attention to the transportation of this type of materials. HMs are defined in the Moroccan law $\mathrm{N}^{\circ} 30-05$ as any material, object or organism which, by reason of its nature, may harm the people, the properties and the environment. No research to our knowledge in this area has been conducted in Morocco to assess the overall situation.

The purpose of this study is to provide a current survey on the situation of HMs in Moroccan companies in order to identify locations, types and classes of HM, logistics chain (supply and shipping), risk management, training of the companies with regard to these materials.

Within this background, the present study aspires to (1) know the companies' methods of supplying and shipping HM (mode, frequency, and type of transport used) and the reasons behind such choices, (2) know the distribution of tasks between the shipper and the carrier during the loading and unloading operations of HM, (3) determine the different storage locations, (4) determine the HM related items representing the largest costs to companies (5) test the ability and willingness of companies to invest in risk reduction measures, (6) know the sector where subcontractors are used for operations related to $\mathrm{HM},(7)$ check the companies' interest / involvement in the activities of their subcontractors, (8) find out the different risk reduction measures, (9) determine the impacts of HM accident, and finally (10) verify whether the current legislation holds industrial activities related to HM or not.

\section{Materials and Methods}

\subsection{Survey by questionnaire}

The survey's objective is to assess the companies' fixed sites and refer to logistic strategies that are adopted by them in terms of HMs. Since the two relevant factors (cost and risk) can affect such strategies, it is essential to understand the role played by these factors within these strategies. To sum up, these have been considered the hearth of the supply chain and have been assessed based on: (a) their procurement practices, (b) their expedition practices, (c) their practices on the site of their company. It is noted that the completion of this questionnaire was based on a study in Canada on the logistics choices of HMs [27].

Table 1: Companies that responded to the questionnaire and their field of activity

\begin{tabular}{|l|c|}
\hline Companies' activity & Numbers \\
\hline Health and pharmaceutical & 3 \\
\hline Automotive industry & 8 \\
\hline Chemistry and oil & 8 \\
\hline Energy \& Research & 7 \\
\hline Aviation industry & 4 \\
\hline Building and public works \& Construction & 5 \\
\hline Food Industry & 5 \\
\hline Transport and logistics & 3 \\
\hline Other industrial activities & 12 \\
\hline Total & 55 \\
\hline
\end{tabular}


This questionnaire was sent to 103 companies that are concerned with HM from different sectors. In a period of 14 months we have received the responses of 55 companies $(53.40 \%)$ as indicated in the Table I which also provides the companies' field of activity.

The questionnaire consists of various sections; each section focuses on a particular aspect of the company activities. These sections are detailed as follow:

\section{a. Company Identification}

This domain of the survey helps gather general information about the company in order to obtain a quick overview (company's name, number of employees, activity area...). And it also used to collect information related to the contact person and allows the transfer of results to the participating company.

\section{b. Identification of a site where there is Hazardous Materials} This part of the survey asks the respondent to identify, among all the installations belonging to the company, a site where there are HM. All the following questions are specific and will be about this site. This choice was made for the sake of consistency in the responses, the nature and intensity of practices that can vary greatly from one site to another. Once the site is identified, the following information are gathered:

- The number of employees on the site;

- The geographical coverage of the site activities;

- The shared part of activities related to HMs;

- The transport of HMs classes found on the site;

- The name of three main HMs found in the site.

\section{c. Supply of Hazardous Materials}

This part of the questionnaire focuses on practices related to the supply of HMs. Supply issues have been separated from shipping issues because these practices may vary depending on these two functions of the company. Some companies supply HM but they ship very little, usually in the form of residual HMs. Questions related to supply issues focus on:

- The number of HMs received on the site;

- The frequency of the receptions;

- The mode of transport used for the supplies;

- The packaging used;

- The conditions surrounding unloading;

- The use of subcontracting.

\section{d. Shipment of Hazardous Materials}

This part of the questionnaire focuses on practices surrounding shipments of HMs. It is considered as a mirror of the previous section on supplies (c), the same questions are asked.

\section{e. Hazardous Material at identified fixed site}

This part is mainly interested in the different places of storage on the identified fixed site. More precisely, the questions can be used to determine whether the company uses temporary storage sites inside or outside its site. In addition, the questions check whether companies have HM transported frequently in order to reduce the quantities on the site.

\section{f. HM Supply related costs}

This part focuses on costs related to HMs. The questions are about:

- The criteria used by the company during these choices of supply, which makes it possible to weight the importance of the cost factor;

- The importance given by the company to various factors related to HMs (specialized vehicles, equipping, training, etc...);

- The maximum percentage increase in operating costs that the company could tolerate to invest in security measures;

- The weighting of the economic impact of different types of accidents on the company.

\section{g. Subcontractors with activities related to Hazardous Materials}

This part of the questionnaire is interested in the use of subcontracting, a common measure to most companies. The objective is in particular to verify if this practice can have repercussions on the security level. The questions asked are relate to:

- The sectors (transport, unloading, on-site handling, packaging, etc.) and where the company uses subcontractors for its Hazardous Materials activities;

- The reason which drives companies to use subcontractors;

- The level of knowledge that companies have about the activities of their subcontractors;

- The type of contracts linking companies to their subcontractors;

- The possible loss of accountability that the business suffers when using subcontractors;

- Measures to monitor the activities of subcontractors;

- The important criteria when selecting a subcontractor.

\section{h. Risk control}

This part of the questionnaire focuses on the risk management measures put in place by the companies. The questions concern:

- The risk management measures put in place on the site and during transport;

- The risk communication policy put in place by the company;

- $\quad$ Procedures surrounding accidents / incident management;

- The possible impacts (immediate direct cost, loss of production, image loss, etc.) of a Hazardous Material accident on the company;

- The relative importance of different types of accidents (fixed site vs. transportation).

\section{i. $\quad$ Regulation Hazardous Materials}

This part of the questionnaire is interested in the manner in which the companies are cooperating in accordance with the regulations on dangerous materials. Among other things, the questions check whether the different regulations (storage, transport) constrain the company's activities and whether, according to them, these regulations make it possible to manage the risk effectively. 


\section{Results}

At this juncture; we shall present the rough results and their analysis. The first part of the chapter is dedicated to the presentation of the results obtained from the fixed sites. The second part analyzes these results and the third part introduces the differences noticed between the small and the large companies that used HMs.

\subsection{Answers obtained}

A total of 103 questionnaires have been supplemented to date. Four of these answers come from an intermediate version from the questionnaire which explains the high number of abstentions to the questions related to the different Residual Hazardous Materials (HMR) received or shipped on the site, frequency training offered, the maximum percentage increase in current operating costs, the economic impact on the business of an HM accident involving employees and public, personnel or departments dedicated to risk management, information or communication on the management of risks to employees, and the organization and planning of on-site activities with clients, suppliers and subcontractors.

The answers to the questions related to the Company Name and the Name of the "contact person" and to the first part of the identification of a site where there are HM are not presented, in order to preserve the identity of the guarantors. Moreover, the answers were compiled and are presented in a grouped way to obtain accurate statistics and to prevent the identifies of the companies from being exposed based on the answers.

The answers obtained come from various horizons: branches of the industry, cuts of the company and portions of the activities related to the HMs.

\subsection{Analysis of the results}

The following parts aim at analysing the answers obtained in the survey in order to establish bonds between the various elements and to draw essential conclusions. In this section, no distinction is made between the various classes of companies.

\subsubsection{Characteristics of the responders}

In this part, we shall deal with the first two sections of our survey. Namely, the identification of companies and the site where HMs are present.

The companies which have answered the questionnaire belong to different sectors, as indicated in Table 2 which also provides the companies sector of activities. Most of them belong to the group of large companies (40\% have between 250 and 5000 employees), and averages companies (38.2\% have between 50 and 249 employees), while a moderate percentage contains small companies (10.9\% have between 10 and 49 employees) as shown in Table 3.

More than half of the guarantors (78.2\%) use more than one site to carry out their activities related to $\mathrm{HMs}$, these sites are divided into two types, factory or warehouse. It should be pointed out that most of the participants, $(69.1 \%)$ are using the factory for these activities (30.9\% using warehouse). These sites have more than one geographic coverage whether it is local, regional or national as shown in Table 4.

Table 3: Number of employees in the companies participating in the survey

\begin{tabular}{|l|c|c|c|}
\hline $\begin{array}{l}\text { Number of } \\
\text { employees }\end{array}$ & Numbers & $\begin{array}{c}\text { Valid } \\
\text { Percentage }\end{array}$ & $\begin{array}{l}\text { Cumulative } \\
\text { percentage }\end{array}$ \\
\hline $\begin{array}{l}\text { Between 250 and } \\
5000\end{array}$ & 22 & 40.0 & 40.0 \\
\hline Between 10 and 49 & 6 & 10.9 & 50.9 \\
\hline Between 50 and 249 & 21 & 38.2 & 89.1 \\
\hline$<10$ & 1 & 1.8 & 90.9 \\
\hline$>5000$ & 5 & 9.1 & 100.0 \\
\hline Total & 55 & 100.0 & \\
\hline
\end{tabular}

Table 4: Geographic coverage of supplies and shipments of the site

\begin{tabular}{|l|c|c|c|c|c|}
\hline \multirow{2}{*}{$\begin{array}{l}\text { Geographic } \\
\text { coverage }\end{array}$} & Answer & Numbers & Percentage & $\begin{array}{l}\text { Valid } \\
\text { Percentage }\end{array}$ & $\begin{array}{l}\text { Cumulative } \\
\text { percentage }\end{array}$ \\
\hline \multirow{2}{*}{ Local } & Yes & 9 & 16.4 & 16.4 & 16.4 \\
\cline { 2 - 6 } & No & 46 & 83.6 & 83.6 & 100 \\
\hline \multirow{2}{*}{ National } & Yes & 23 & 41.8 & 41.8 & 41.8 \\
\cline { 2 - 6 } & No & 32 & 58.2 & 58.2 & 100 \\
\hline \multirow{2}{*}{ Regional } & Yes & 9 & 16.4 & 16.4 & 16.4 \\
\cline { 2 - 6 } & No & 46 & 83.6 & 83.6 & 100 \\
\hline \multirow{2}{*}{ Another } & Yes & 24 & 43.6 & 43.6 & 43.6 \\
\cline { 2 - 6 } & No & 31 & 56.4 & 56.4 & 100 \\
\hline
\end{tabular}

When talking about Small and Medium Enterprises (SME), there is no doubt about their essential function in the Moroccan national economy. They represent the bulk of the entrepreneurial fabric, a proportion exceeding $95 \%$ and occupying more than $50 \%$ of private sector employees. The share of SMEs in Moroccan exports and domestic private investment is respectively around $31 \%$ and $51 \%$. These entities play a vital role in promoting the social dimension as well as in the economic and territorial development.

The SME is present in all sectors of Moroccan economic activities: industry, crafts and construction, businesses and services that include tourism, communications, transport, financial services. In the industrial sector in particular, the SME accounts for almost half of the total as follows: textiles and clothing (35\%), chemistry and para-chemistry (26\%), agri-food (24\%), mechanics and metallurgy ( $12 \%)$, electrical and electronic (3\%) [28].

According to the Moroccan Ministry of Industry [10], the most influential industrial sectors in the national economy are: the automotive industry for that Morocco is considered as the first construction hub on the African continent, followed by other sectors such as Aeronautics, Textile; Leather, Electronics, Electrical, Chemical-Parachemistry, Pharmaceutical, Building Materials, Renewable Energy and Mechanical and Metallurgical Industries (IMM). This explains the rations and sectors related to 
Table 2: Sector of activities of the companies participating in the survey

\begin{tabular}{|c|c|c|c|c|}
\hline Activity sector & Numbers & Percentage & $\begin{array}{c}\text { Valid } \\
\text { Percentage }\end{array}$ & $\begin{array}{c}\text { Cumulative } \\
\text { percentage }\end{array}$ \\
\hline Health and pharmaceutical & 3 & 5.5 & 5.5 & 5.5 \\
\hline Automotive industry & 8 & 14.5 & 14.5 & 20.0 \\
\hline Chemistry and oil & 8 & 14.5 & 14.5 & 34.5 \\
\hline Energy \& Research & 7 & 12.7 & 12.7 & 47.3 \\
\hline other industrial activities & 12 & 21.8 & 21.8 & 69.1 \\
\hline Aviation industry & 4 & 7.3 & 7.3 & 76.4 \\
\hline building and public works \& Construction & 5 & 9.1 & 9.1 & 85.5 \\
\hline Food Industry & 5 & 9.1 & 9.1 & 94.5 \\
\hline Transport and logistics & 3 & 5.5 & 5.5 & 100.0 \\
\hline Total & 55 & 100.0 & 100.0 & \\
\hline
\end{tabular}

the hazardous substances involved in this research. Not all the companies that answered the questionnaire are specialized in handling of HMs. About one fourth $(21.9 \%)$ of the obtained answers comes from companies belonging to other industries whereas the other half comes from related companies of different sectors.

The Figure 1 shows the percentage of companies whose part of their activities at the site is related to HM.

We have found that there are various classes of HM on the site of the median company where most present classes are the flammable liquids $(56.4 \%)$, the gases $(40 \%)$, and the corrosive substances $(29.1 \%)$. The rarest classes are the radioactive materials $(7.3 \%)$ (figure 2). Among the various dangerous substances listed on the sites, one is generally found: gasoline, GPL (Butane), sulphuric acid and xylene.

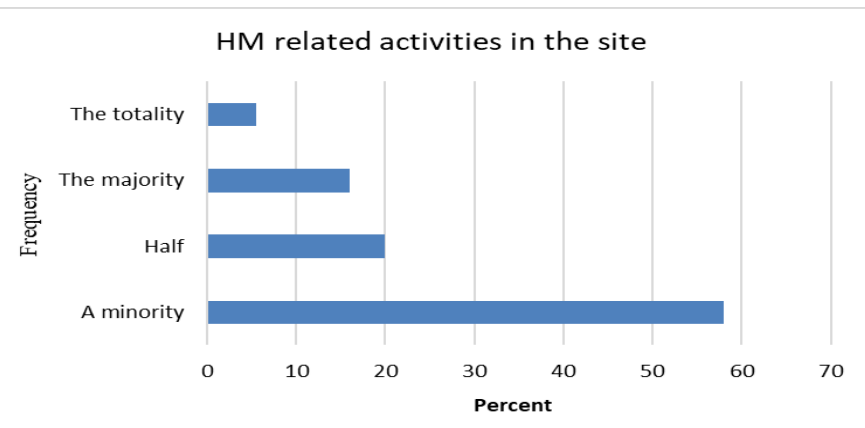

Figure 1: HM related activities in the site

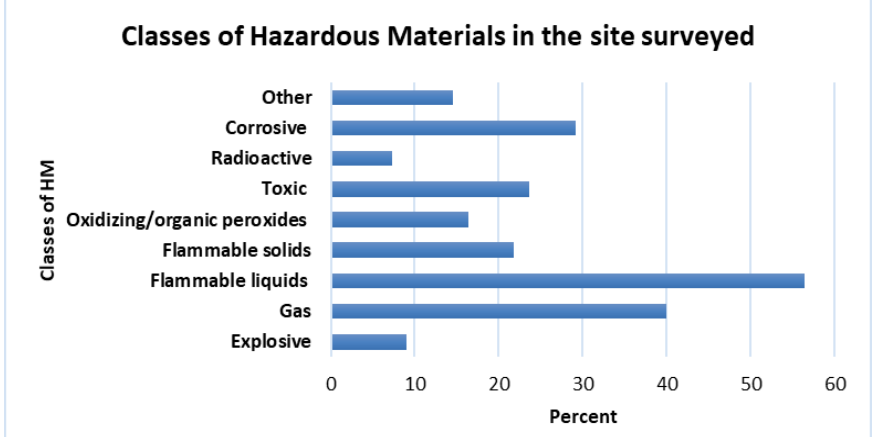

Figure 2: Classes of Hazardous Materials in the sites surveyed
Concerning the classes of HMs imported or exported through the port of Tangier Med in 2017 [29], we have noted, based on some received statistics, that the most transported classes, as shown in Figure 3, are as follows: the flammable liquids (36\%), corrosive substances $(19 \%)$, the gases $(40 \%)$.

Concerning Class 1 (Explosive) and Class 7 (Radioactive Materials), their presence constitutes small percentage due to the special procedures used to transport the materials of these two classes, which require the approval of a special commission to be imported, exported or transported. In [30], some examples of the procedures used in the port national agency for these two classes depending on the Moroccan law have been cited.

\section{Classes of HM imported or exported through the port of Tangier Med}

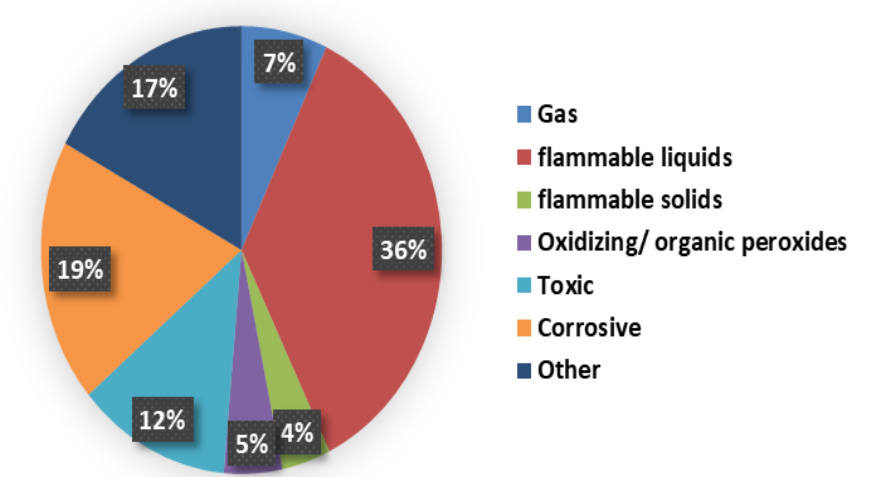

Figure 3: The classes of Hazardous Materials imported or exported through the port of Tangier Med in 2017

\subsubsection{Provisioning and forwarding}

The great majority of the guarantors (70.9\%) affirm receiving dangerous substances or products controlled on the identified fixed site, and just $27 \%$ of the companies that make the shipment of HM or products controlled from their site as shown in the following graphic: 


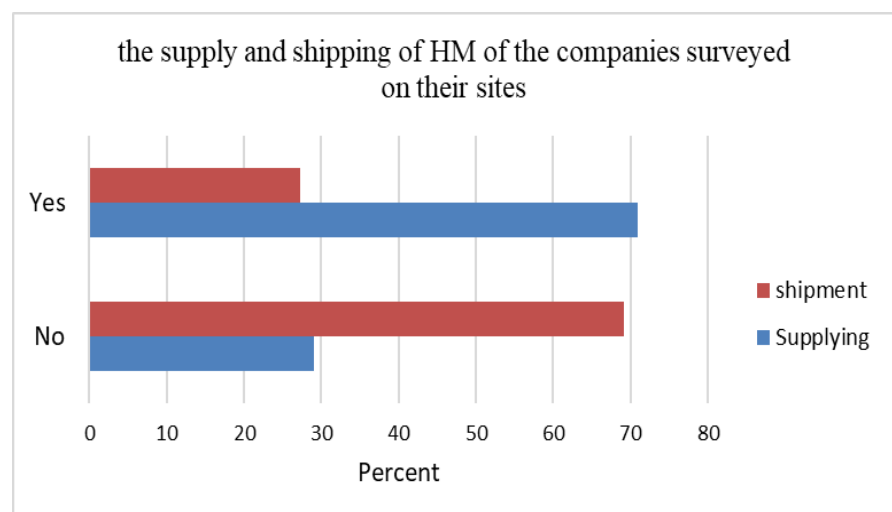

Figure 4: The supply and shipping of Hazardous Materials of the companies surveyed on their sites.

This is explained by the presence of companies consumers and non-producers of HM within the sample. The majority (27.3\%) of the companies affirm the treatment of five different dangerous substances or more (figure 5). The very great majority of the companies $(79.8 \%)$ receives dangerous substances during the month, the week or few times a year.

In contrast, we found the majority (10.9\%) of $25.5 \%$ of companies affirming the shipment of HMs from their sites, averred that they treat five different dangerous substances or more. The very great majority of the companies (28.6\%) ship HMs during the day, 23.8\% during the month or a few times a month, 19\% during the week (figure 6).

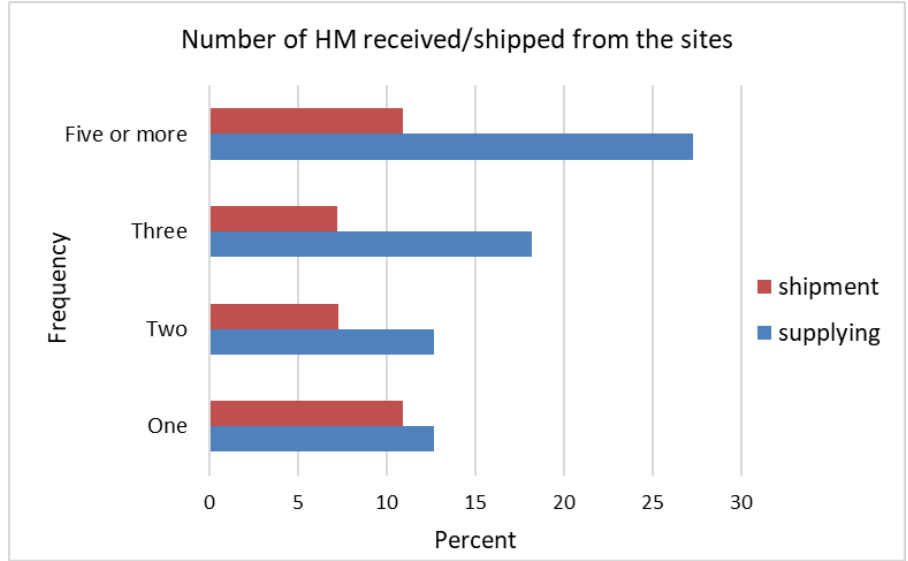

Figure 5: Number of Hazardous Materials received/ shipped from the sites.

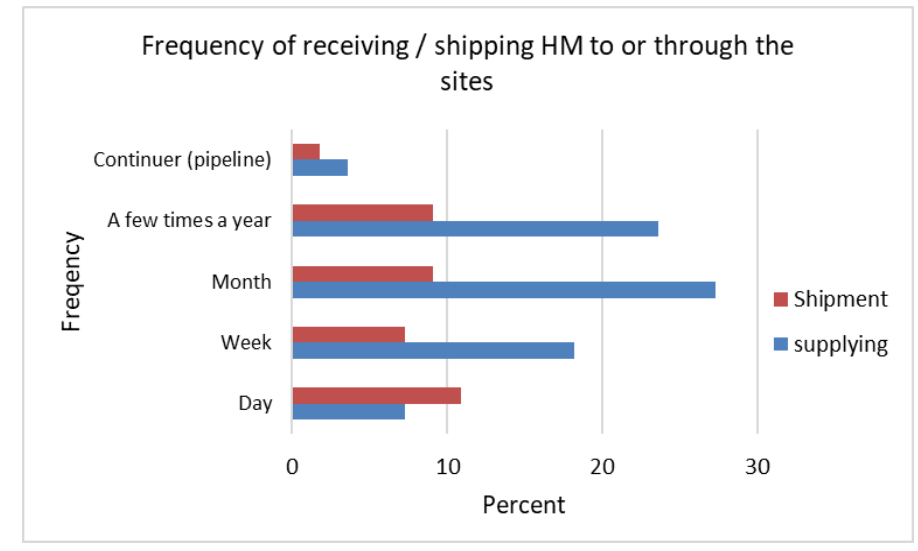

Figure 6: Frequency of receiving/shipping HM to or through the sites.
The means of transport preferred for the provisioning are, respectively (figure 7$)$ : the truck $(74.5 \%)$, the train $(5.5 \%)$, the boat $(27.3 \%)$, pipeline $(3.6 \%)$ and the plane $(1.8 \%)$. The strong preponderance of the truck can surprise at first sight, but recall that according to the questionnaire, a company would notch this choice recourse to a means of transport, even if it is in an occasional way. The percentages collected cannot thus be translated into mileage, tonnage or a number of sending. We have also found that the most common mode of transportation is the conditioned mode (67.3\%), which bulk transport just $18.2 \%$ of respondents who affirmed who are using its use.

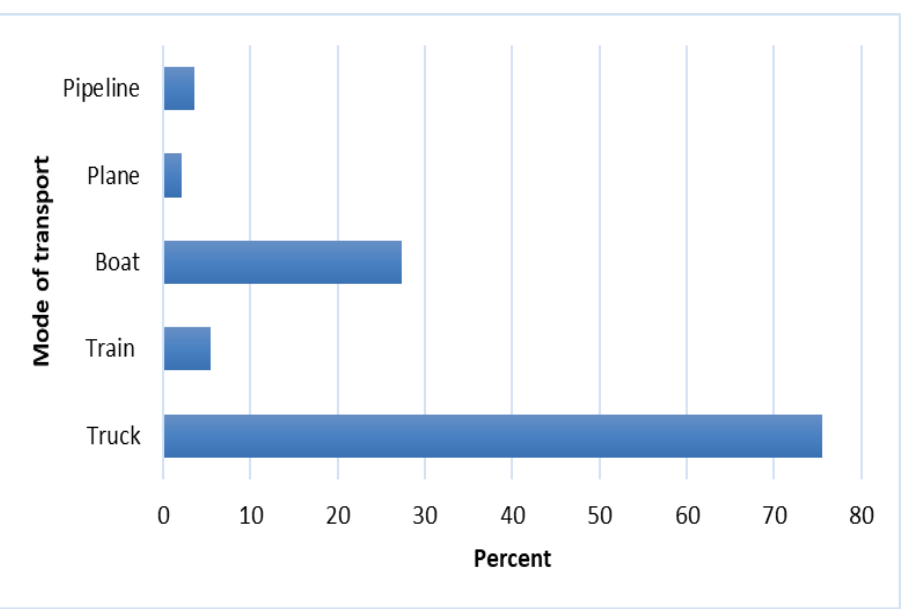

Figure 7: Mode of transportation used to transport HM

A high number of companies affirm that it would be impossible to change means of transport. The majority of the other companies affirm that they could change means of transport only for some substances but not for all the substances. It should be recalled here that the choice of a means of transport is largely influenced by the proximity of the infrastructures of transport.

Very few companies $(12.7 \%)$ carry out truck transport on their own. This task is usually assigned to the supplier $(41.8 \%)$ or to a third-party carrier (23.6\%) (Figure 8). However, the majority of the companies supervise the unloading of the dangerous substances (41.8\%) and in many cases carry out unloading $(21.8 \%)$. There are on the other hand some companies that uses a subcontractor (5.5\%) (figure 9).

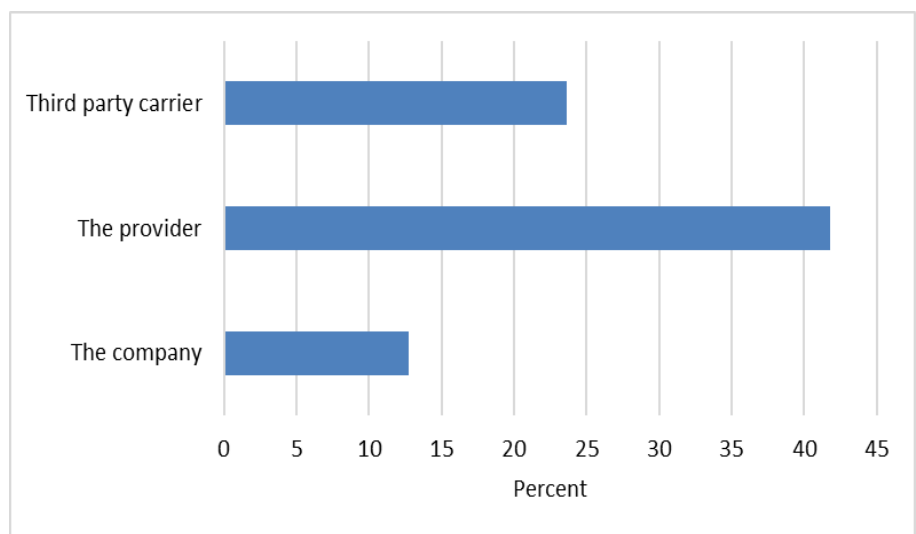

Figure 8: Responsible for truck transport. 


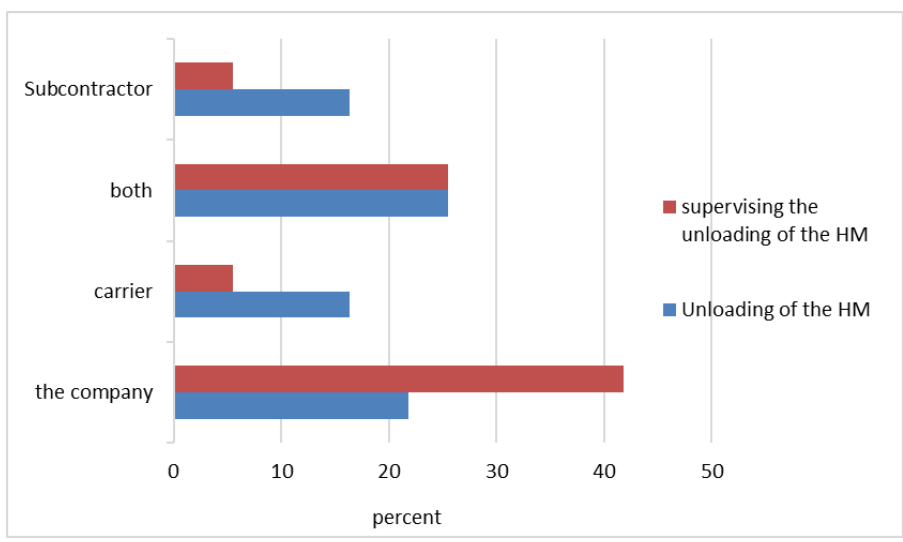

Figure 9: Supervising the unloading of HM or HMR in supply.

\subsubsection{Hazardous Materials (HM) at fixed site}

The training offered to the employees working with the quays of shipping/receiving is often offered by a consultant (39.2\%), yet the majority $(56.4 \%)$ of the employers are concerned too, as shown in Figure 10. This training is often offered during the recruitment $(47.3 \%)$ or even annually (47.3\%). Among the surveyed companies only (3.6\%) announce that they offer this training in three years (Figure 11). The other companies include it with other trainings sessions at the time of recruitment or with the requirements.

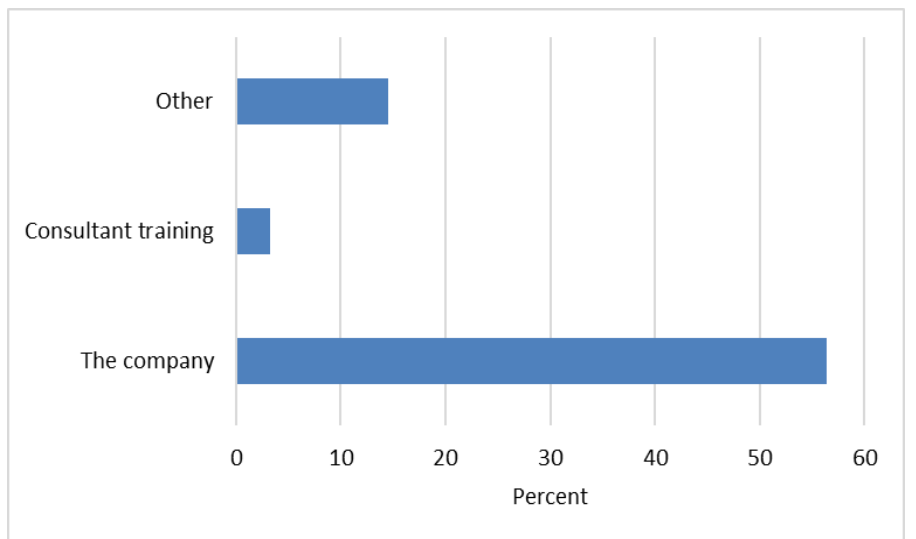

Figure 10: The training offered to the employees of the shipping/receiving.

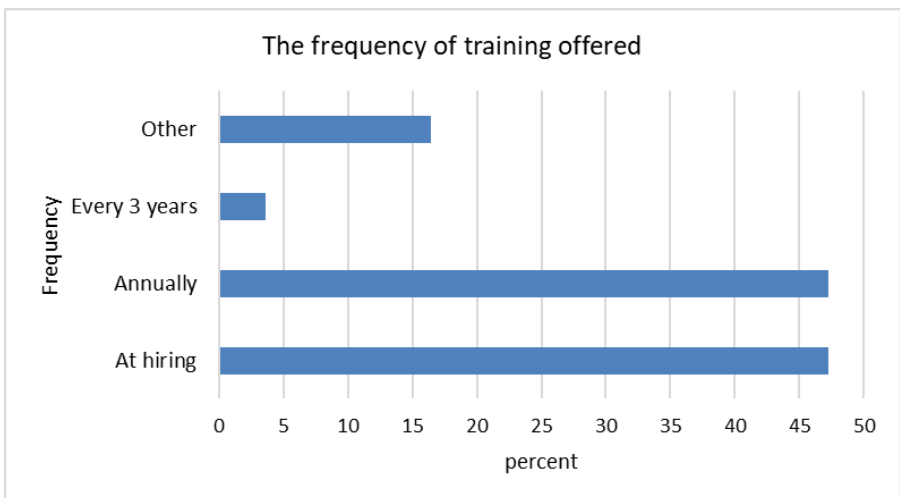

Figure 11: The frequency of training offered to the employees at site.

The majority of the companies (54.5\%) always or often use zones dedicated to HM. Some companies however affirm that they're used only sometimes $(10.9 \%)$ or even rarely $(10.9 \%)$. In the opposite way, it is not frequent that dangerous substances are stored in a temporary way on the site of the company. A few companies $(21.8 \%)$ have even stated that they often if not always have recourse to this practice.

On the other hand, temporary storage outside the site is not very widespread. Only $16.3 \%$ (3.6\% always, $12.7 \%$ sometimes) of the companies use temporary storage on a site which does not belong to their own company, whereas temporary storage on other sites belonging to the company touches $18.2 \%$ of the guarantors $(5.5 \%$ always, $12.7 \%$ often).

The majority of the companies affirm that they transport HM more often in order to avoid having too much of it on the site. A considerable share of the companies $(65.5 \%)$ affirm that they have recourse to this practice always $(12.7 \%)$, very often or sometimes $(52.8 \%)$, whereas $21.8 \%$ of the companies say that they never do it, as shown in figure 12 below. This contributes to the increase in the number of convoys on the roads, although the quantities remain the same.

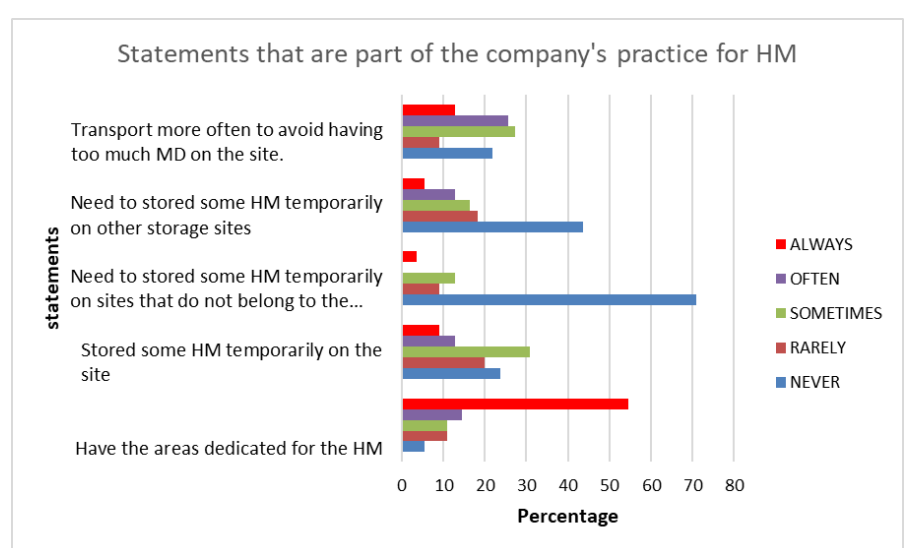

Figure 12: Statements that are part of the company's practice for HM.

\subsubsection{Costs related to HM supplies and shipments}

The majority of the companies (85.5\%) are ready to invest more in safety since the sums do not exceed a certain level. In the vast majority of cases, this level is below $5 \%$ (for $20 \%$ of them) or even $10 \%$ (for $14.6 \%$ of companies that have answered) on current operating costs (figure 13).

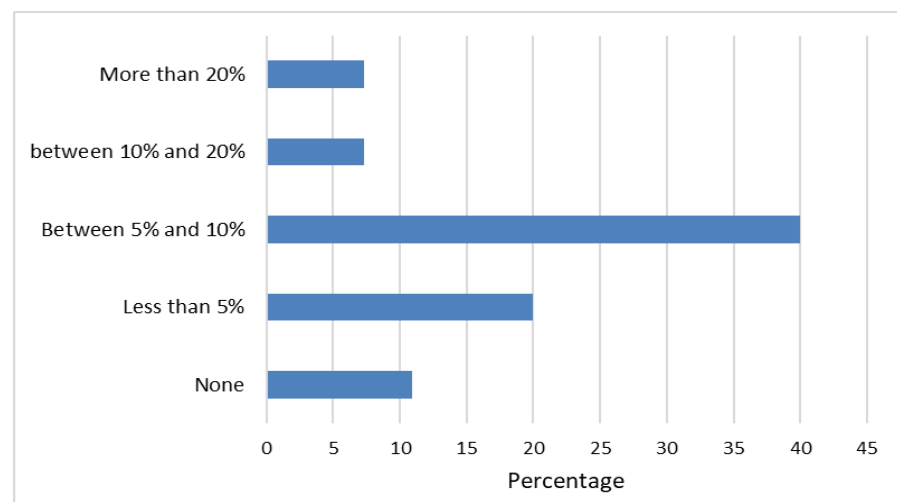

Figure 13: Percentage of current operating costs that companies would invest for security measures. 
Moreover, when they make their choices of provisioning or HM forwarding, the criterion "Transport security" is mentioned very often $(89.1 \%)$ followed by the "cost of transport" (83.6\%) then the "cost of storage" $(70.9 \%)$ as shown in figure 14.

Several companies did not classify their answers in order of importance, but even with fragmentary results, this classification offers a distribution similar to the one mentioned so far.

The most frequently mentioned HMs items when referring to costs as shown in figure 15 are, in order: equipment on the site and employee training (74.6\%), security audits (69.1\%), specialized vehicles $(67.4 \%)$, regulatory measures $(65.5 \%)$, General insurance premiums $(56.4 \%)$ and hiring of a security manager $(52.7 \%)$. The insurance premiums $(52.7 \%)$ and the accidents/incidents HM (49.1\%), are less often mentioned.

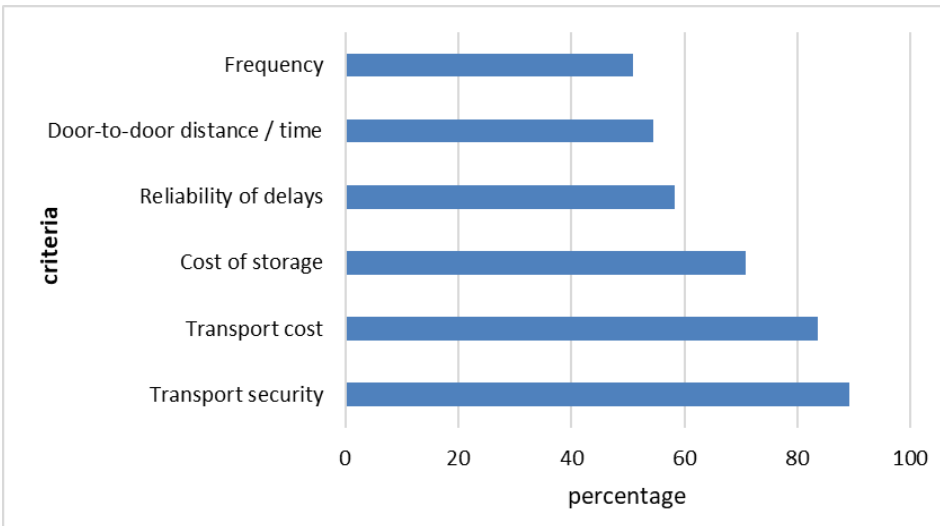

Figure 14: The criteria that are important when the company makes its choice of HM supply or shipments.

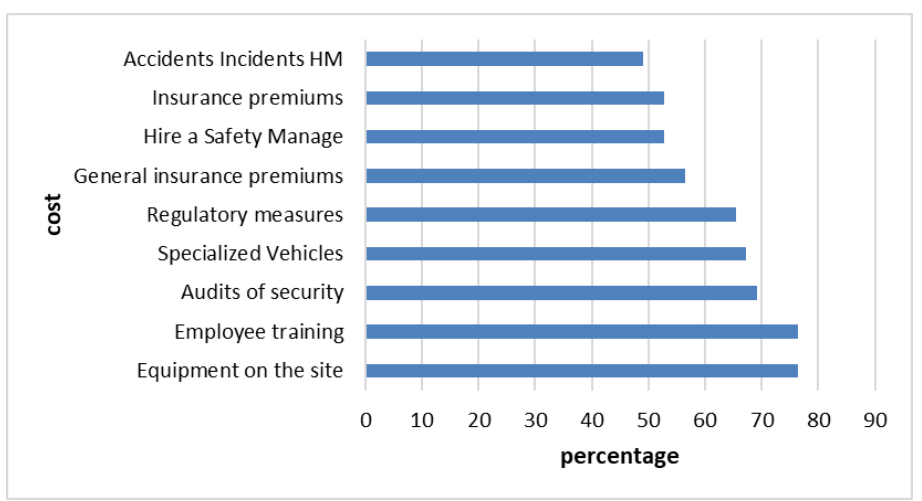

Figure 15: The costs incurred by HM represent a significant burden for the company.

The guarantors had to consider the economic impact of three types of accidents (with spill, implying employees, implying the public) compared to the economic impact of an accident isolated without discharge. In the three cases, the companies have estimated that the impact would be more important, and their evaluation of the possible impacts on their company increases with each new scenario. Indeed, $16.4 \%$ of the guarantors have estimated that the impact would be much more important for an accident with spill whereas this proportion grows to $32.7 \%$ for an accident involving employees and to $36.4 \%$ for an accident involving the public. We have www.astesi.com noticed, however that some guarantors have estimated that the impact would be similar if the accident implied employees or the public (figure 16).

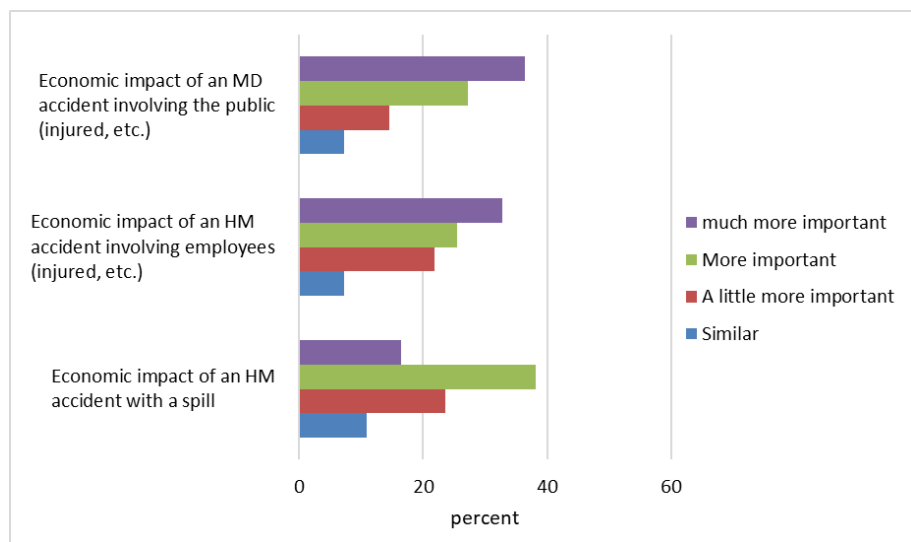

Figure 16: The economic impact of an HM accident on the company.

\subsubsection{Subcontractors with activities related to $H M$}

All companies use subcontractors for any of their HMs activities. The areas where they are most popular as shown in figure 17 are, in order: transportation ( $45.5 \%$ supply and $34.5 \%$ shipping), loading $(40.5 \%)$ and unloading (34.5\%). On the other hand, a few companies use the services of subcontractors on their site, whether while handling $(27.3 \%)$, packaging $(25.6 \%)$, storing $(18.2 \%)$ or producing $(18.2 \%)$.

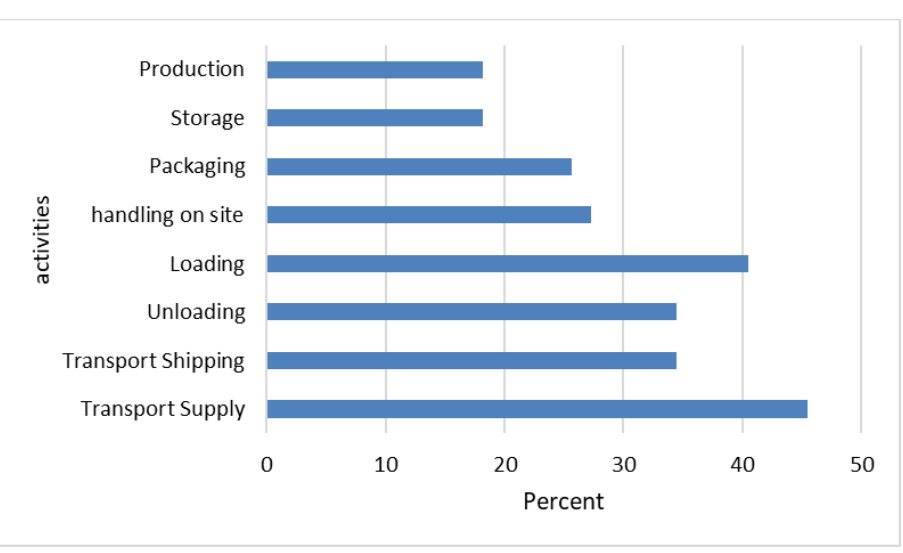

Figure 17: Subcontractors in HM activities.

Regarding the use of subcontractors for transport, companies mainly cite: the fact that they do not have the expertise $(23.6 \%)$ and the fact that the carrier shares the responsibility of the risk $(25.5 \%)$, the costs $(16.4 \%)$ and the fact that they do not have vehicles $(9.1 \%)$ as illustrated in figure 18 . Conversely, the most cited reasons for not using subcontractors are risk management $(32.7 \%)$ and costs $(14.5 \%)$ or other reasons $(23.6 \%)$.

A number of elements point to a tendency towards disempowerment. For example, several respondents have claimed that the impact of a transport accident made by their subcontractor would have a zero impact on their company (20\%) or lower $(25.5 \%)$ than an accident, with their own vehicles. Besides, $25.5 \%$ have said that they never perform safety audits of their subcontractors while only $20 \%$ have stated that they always do. When we combine these few elements with 
the fact that $16.4 \%$ of the companies know perfectly well that their subcontractors delegate in their turn to subcontractors $(29.1 \%$ ignore it and $5.5 \%$ are vaguely aware of it), one can easily realize the extent of the phenomenon of disempowerment in transport.

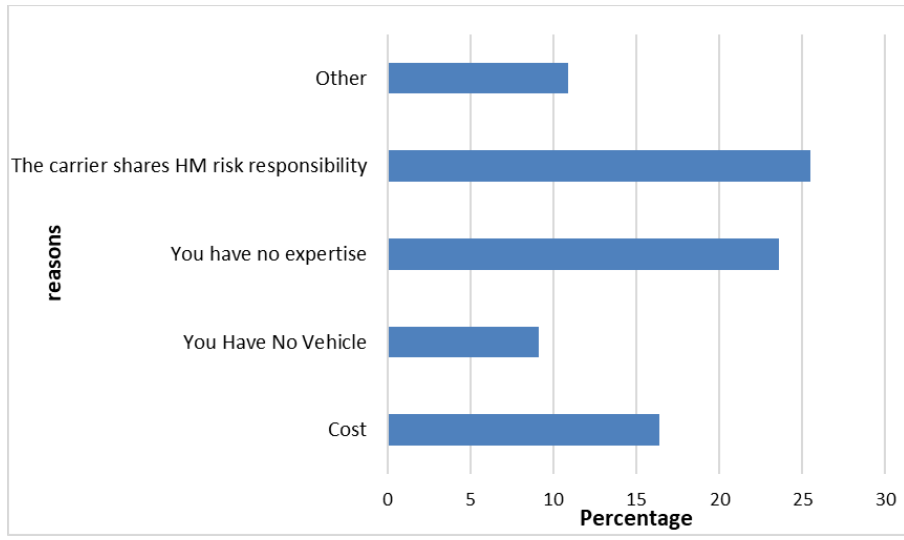

Figure 18: Reasons for using the subcontractors in the transport activities.

Regarding the contracts of these companies with their subcontractors, $10.9 \%$ of respondents still use longterm contracts with their subcontractors while $21.8 \%$ have mentioned that they never use them (Figure 19). When it comes to the selection of the subcontractors targeted by these contracts, companies are mainly concerned with: reliability / quality of service $(72.7 \%)$, control of safety $(70.9 \%)$, cost $(69.1 \%)$, ISO certifications $(60 \%)$, the ability to track transportation $(52.7 \%)$, carrier reputation $(50.9 \%)$ and past accidents $(50.9 \%)$. The possibility of establishing a lasting relationship $(45.5 \%)$ receives less attention, although they are also considered important by many companies (figure 20).

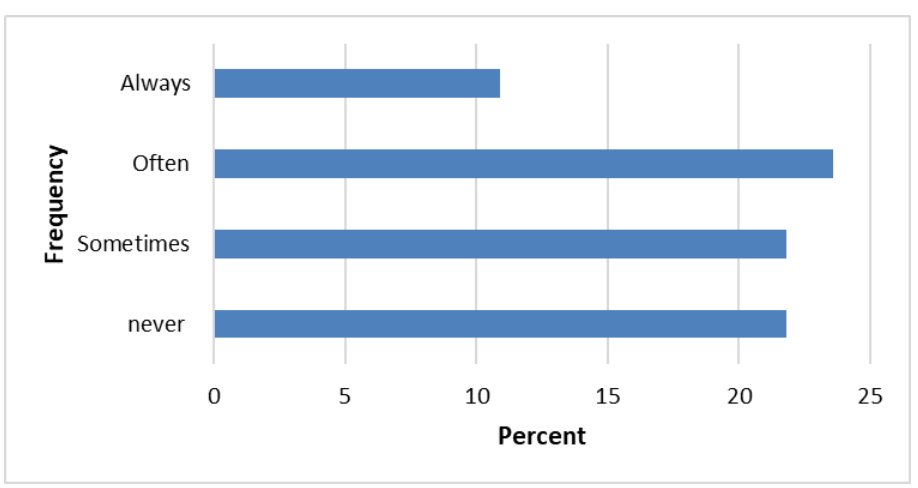

Figure 19: Long term contracts between the company and their subcontractors.

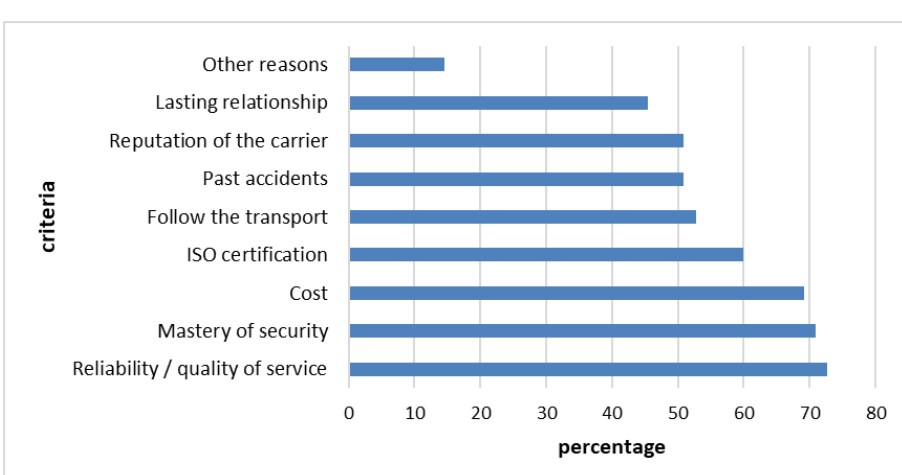

Figure 20: The relevant criteria while selecting a carrier for HM.

\subsubsection{Risk management}

Almost all companies report performing risk analyses on their site, in spite of numbers such as never $(7.3 \%)$ rarely $(7.3 \%)$ or sometimes $(16.4 \%)$. On the other hand, they are less likely to do risk analyses for transportation; a number of companies never do $(16.4 \%)$, rarely $(10.9 \%)$ or sometimes $(21.8 \%)$ and only $21.8 \%$ always do, unlike $34.5 \%$ in fixed site. This is because a large number of companies outsource transportation activities. Similarly, companies are more likely to have stricter procedures than the law on their site for transport $(23.6 \%$ still use more stringent procedures than the law on the site, against $16.4 \%$ for transport). Additionally, few companies $(18.2 \%)$ use tracking technologies (GPS, etc.) to transport HMs ( $40 \%$ never use them) (figure 21).

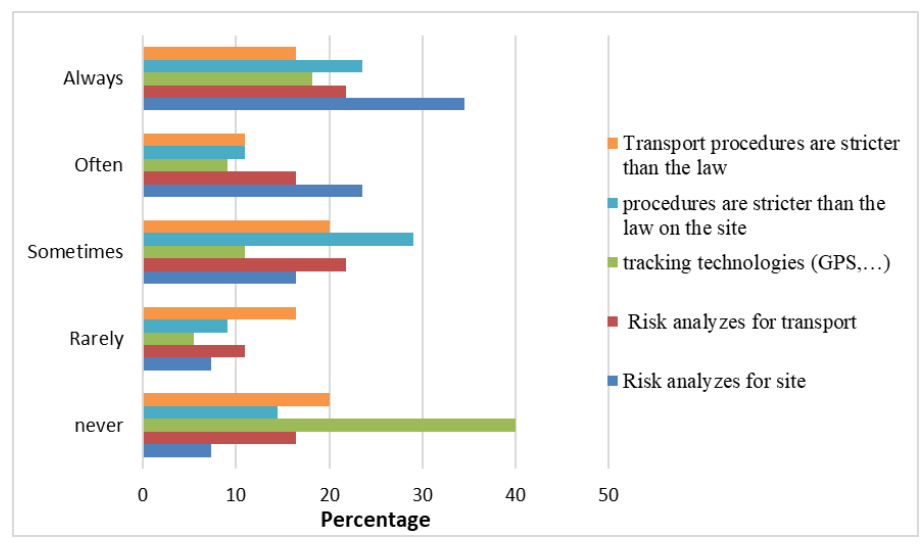

Figure 21: Risk management for the surveyed companies.

A few companies communicate their risks with citizens, whether for their site (12.7\% always do it) or for transport (7.3\% always do), but many companies use their risk management to enhance their image with $29.1 \%$ of respondents who have said that they never do it, as shown in figure 22.

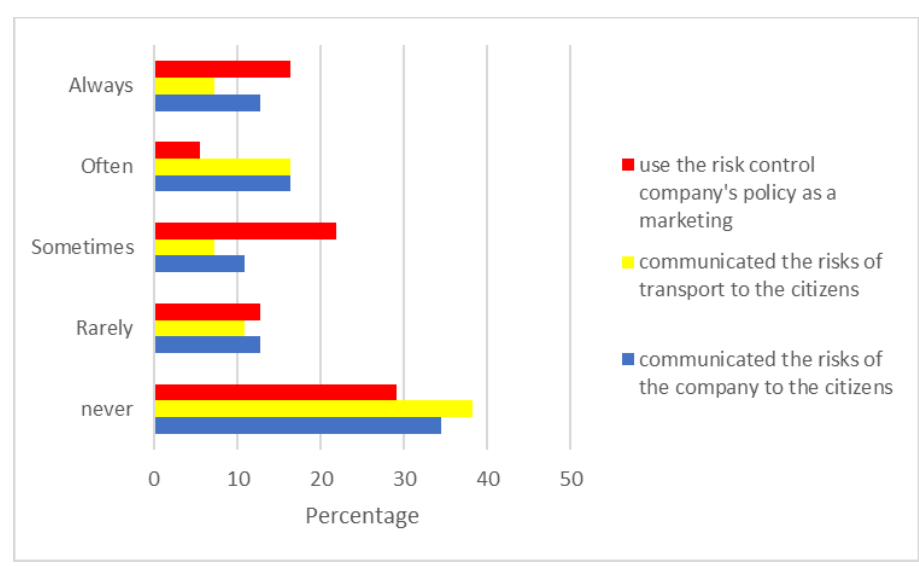

Figure 22: Risk communication in the surveyed companies.

The majority of respondents $(52.7 \%)$ still claim that they use specific procedures while loading and unloading HMs. Though, some companies never use them $(16.4 \%)$, rarely $(3.6 \%)$ or sometimes $(16.4 \%)$. On the side of the various risk management programs, we have observed the same situation. Most companies offer risk management information/communication sessions to their employees $(69.1 \%)$, have a workplace health and safety 
committee $(69.1 \%)$, and have dedicated risk management staff (61.8\%), or a prevention program specific to HM (61.8\%) (figure $23)$.

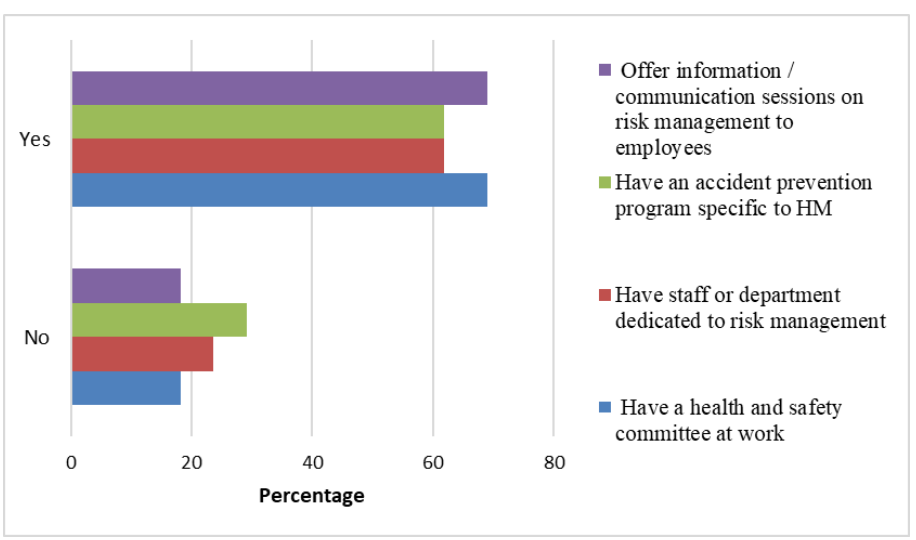

Figure 23: Risk management programs in the surveyed companies.

When the companies are questioned about the possible impacts of an HMs accident (in transport or on the site) on their company, the companies answer respectively, as shown in figure 24: the direct cost $(70.9 \%)$, the loss of image $(65.5 \%)$, the loss of production $(65.5 \%)$, the loss of customers $(60 \%)$, the increase in insurance premiums $(58.2 \%)$ and the reaction of citizens $(45.5 \%)$.

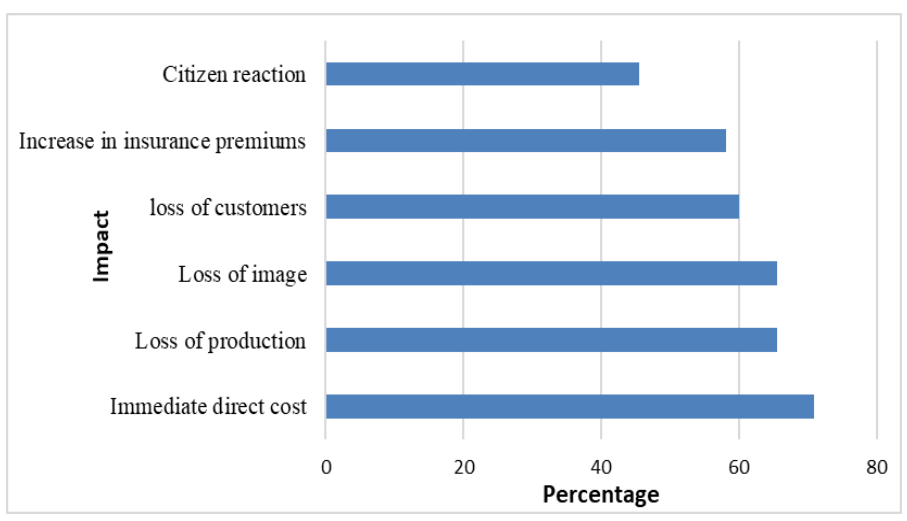

Figure 24: The possible impacts on the company in case of HMs accident.

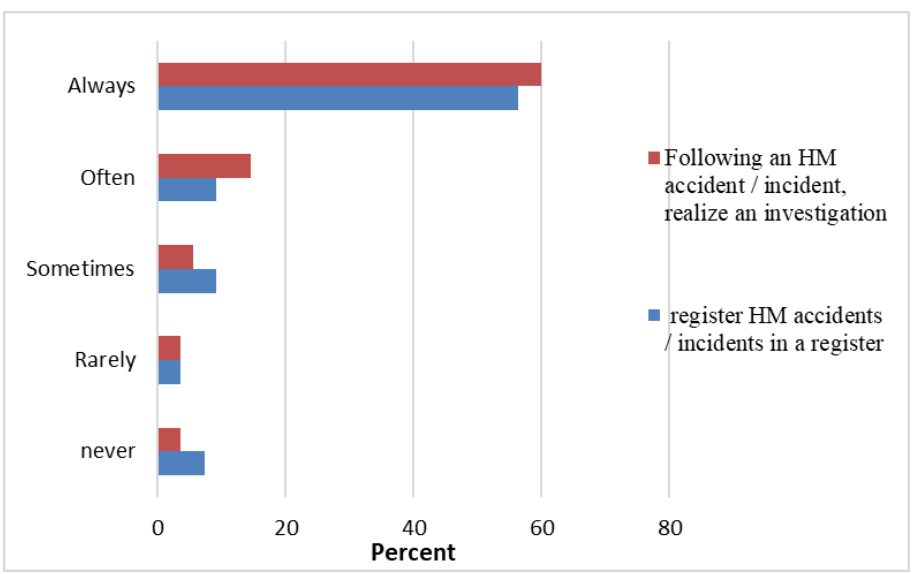

Figure 25: Accident/incident management for the surveyed companies

Most companies (56.4\%) still list these accidents in a register, although $7.3 \%$ of respondents say they never do so and $3.6 \%$ rarely do. In the same way, $60 \%$ of the companies always carry out investigations following these accidents whereas $3.6 \%$ of the companies affirm that they never do it (Figure 25).

In the opinion of many companies, a fixed-site accident (49.1\%) would have a greater impact than a transport accident $(18.2 \%)$, as shown in figure 26.

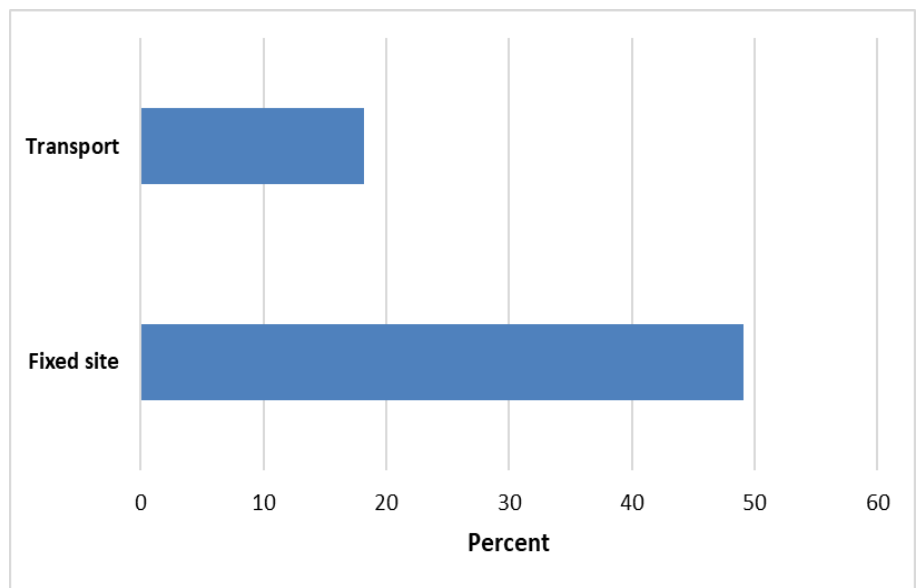

Figure 26: Type of HM accidents and their weight on the companies.

\subsubsection{HM Regulation (Law No. 30-05 on the transport of dangerous goods by road)}

Many companies claim that HM regulations (site, transportation, health and safety) restrict their day-to-day activities with only $23.6 \%$ of companies saying they never limit them. Storage regulations seem to be the one that restricts businesses the most. On the other hand, $30.9 \%$ of companies say that Health and Safety at Work regulations never limit them and $29.1 \%$ of companies say that transport regulations never limit them (figure 27). It should be remembered, however, that the majority of companies do not perform the transportation themselves, which may influence their perception of transportation regulations.

Due to the limitations imposed by the storage regulations, several companies had to: make substitutions of materials (54.6\%), reduce their stocks of HMs $(61.9 \%)$ or change their logistical choices and delivery frequencies $(52.7 \%)$ (figure 28 ).

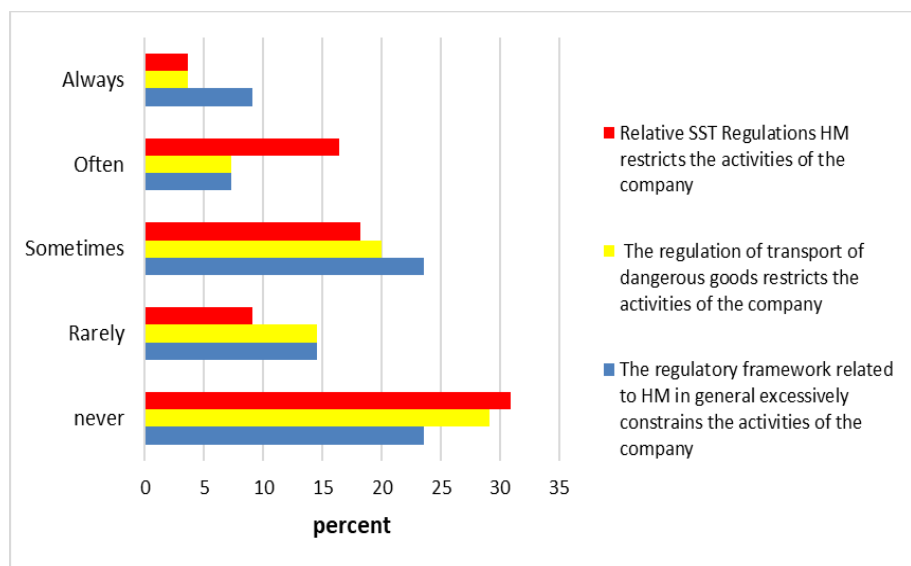

Figure 27: The affirmations related to the HM regulation according to the surveyed companies. 


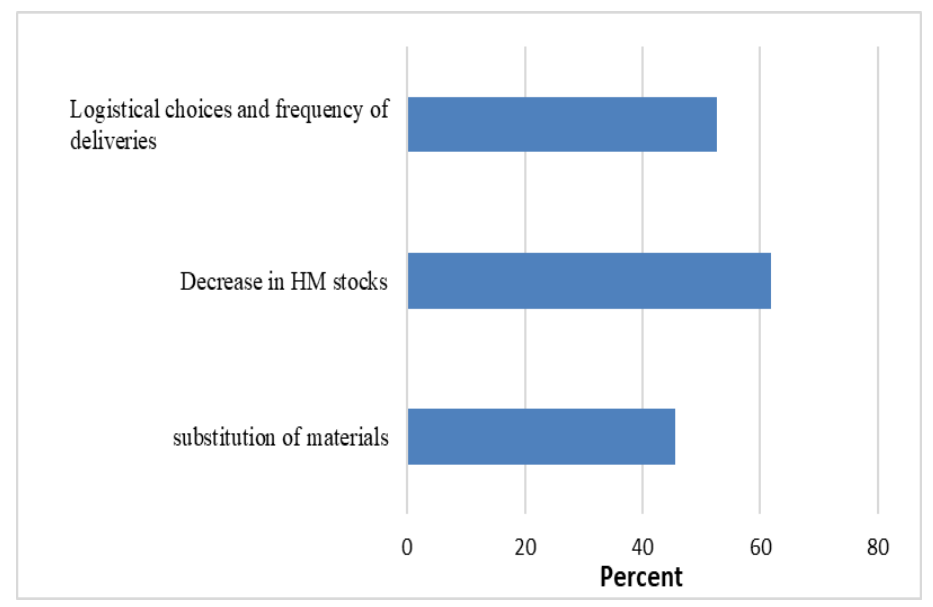

Figure 28: The choice of modifications that can be made by companies according to HM storage regulations.

\section{Discussion}

Our primary objective is based on the development of this part of the study by examining the nature, quantity and routes of HM in circulation in Morocco. Unfortunately, while we were doing this research, there was a lack of information and statistics on HMs even among the services and state agencies. As a result, it was difficult to formulate a coherent and precise idea on this question at the national level. That can be attributed to several reasons, the most important of which is the absence of an exhaustive official inventory of HM currently circulating in Morocco, only a few fragmentary statistics are available. They are carried out in the places of production and consumption without indicating the precise nature of the substances transported.

The classification adopted by Morocco is that developed by the UN. When examining the data from our survey, we can conclude that the classes of the most dangerous substances transported in Morocco are flammable liquids, gases and corrosive substances (figure 4), so the transport administration must be aware of the danger that major accidents that may occur, such as:

- fires and / or explosions caused by flammable materials;

- serious disorders related to inhalation or ingestion of certain toxic substances etc.

The industrial sector ranks second in the Moroccan economy [31], so the range of dangerous products, which are mainly manufactured products in circulation, is not very wide. The hydrocarbon sector and its derivatives are the ones that accounts for the majority of safety concerns related to hazardous substances transported. This sector is important on the national scale, with two respects:

- the preponderant and vital role of hydrocarbons in the country's economy;

- the largest volume of hazardous substances carried is that of hydrocarbons and their derivatives.

Hazardous substances imported or produced and distributed in Morocco mainly use the road to reach their destination (Figure 9), the mode which represents more than $75 \%$ of the national freight [32].
The analysis of accidents caused by HMs, as indicated in [17] have shown that these accidents are significantly highly occurring during the transport of theses HM, followed by accidents occurred in processing plants and storage facilities. In contrast, most domino accidents are found in storage area, followed by process plants and transportation [13], which are mainly caused by LPG, petrol and gasoline [13].

Road transport of hazardous substances has the advantage and the convenience of directly linking the producer and the consumer. In this case, the quantities transported packaged or in bulk, are relatively less important (a few tons to a few tens of tons). This also allows, at least in theory, to reduce the risk of accidents by minimizing the handling and unloading-loading operations. Moreover, users of dangerous substances can be scattered throughout the national territory. In fact, the majority of companies that produce or use as raw material the dangerous substances are concentrated in Casablanca and its surroundings and also the region of Tangier. Nevertheless, this is not a safety advantage as accidents in urban and suburban areas can be particularly disastrous.

The fact that Morocco has a fairly large network of national roads and interurban highways is an asset for the road transport of dangerous substances. Most of the accidents, in which they are involved, are resulted from vehicle failures. More precisely from the imprudence of the transport professionals.

Among the dangerous products transported are flammable liquids, gases and corrosive substances, which is represented in [21] as the most frequent hazmat tanker accidents. The rarest materials are radioactive materials (Figure 2 ).

Even if the increase in the number of tankers used to transport oil and other dangerous substances is justified by the ever-increasing demand for these products, which are essential for economic activity, the fact remains that this activity generates a multitude of potential dangers (fires, explosions, intoxications, negative impacts on the environment).

The constraints of competitiveness and productivity imposed on industrial, mining and agricultural stakeholders, mean that the transportation of these products to the exploitation sites is carried out at a frantic pace and generally without much precaution. Moreover, the multiplicity of the risks of pollution and the various other dangers that this field of transport provokes is often unpredictable, to the point that in the event of an accident, these risks took the appearance of a catastrophe not only for the environment but also for users (the populations).

For example, the accidental spillage of flammable, explosive or highly toxic products is always the most dangerous because the damage caused would be disastrous.

Unlike the road network which covers the entire national territory, the rail network for the transport of $\mathrm{HM}$ is limited to Atlantic Morocco with two axes serving the Northeast (Oujda) and Central West (Casablanca) respectively. A good part of this network is reserved for the transport of phosphates.

With the recent development of passenger transport, the Moroccan railway does not offer a large place for goods in general, and even less for dangerous goods. The ones it is 
accustomed to and continues to transport are always connected to phosphate (phosphoric acid, sulfuric acid, fertilizer). Explosives are also among the dangerous substances carried by the railways. The administration of ONCF applies strict regulations on them, and no major accident has ever occurred.

The transport of dangerous goods by rail was regulated by the Dahir $\mathrm{n}^{\circ} 1-01-223$ of 30 August 2001, confirming the ratification by Morocco of the Convention concerning International Carriage by Rail (COTIF) and its appendix on the transport of dangerous goods better known. also, under the initials RID [33].

In terms of risk management, the results show that $47.3 \%$ of companies received HMs training for the entire supply chain during recruitment and thereafter on a yearly basis (Figure 10). So, the majority of companies expressed their willingness to supply security equipment and almost all companies have shown that the choice of HM supply or shipments is based primarily on the criteria of transport security (89.1\%) and transport cost $(83.6 \%)$ as shown in Figure 14.

The data analysis also highlighted some specific characteristics. Most accidents are due to operations such as the loading / unloading of HM as indicated in [13], these operations as shown in our research (Figure 17) are dedicated mainly to the subcontractor, it seems that an additional effort should be devoted to improve the security of these procedures, including stricter legislation and better training.

It is reminded that the decree of application of the law 30-05 relating to the road transport of dangerous goods was published in the Official Bulletin on June 30, 2011 [30]. The law fixes the conditions of security imposed on the carriers and envisages sanctions and sentences ranging from one month to two years and fines of DH 2,000 to DH 100,000. In order to align with European standards for road transport of dangerous goods, more precisely with European Agreement on International Transport of dangerous goods by road, known as ADR. Law 30-05 determines all the conditions applicable to this type of transport: from loading to unloading, from the conditions of use of the vehicles to the obligations incumbent on the operators in the operation.

Though Morocco is among the first signatory countries to these agreements, the application of these agreements is not yet widespread because of lack of implementing legislation. As a result, with the exception of oil companies and multinationals, most tanker drivers do not distinguish between a potato load and radioactive or explosive material. Several Moroccan companies organize ADR training for the benefit of their drivers and can travel in Europe without any problem to transport dangerous goods on European soil. There is no point in passing a law if it is not applied in the field. What we are seeing now is that some customers are not demanding and always favor the cost factor at the expense of security.

Several accidents caused by tanker trucks had serious economic, social and environmental consequences. Since 2007, the Bouregreg Watershed Agency has sued two carriers for accidentally spilling part of their oil load. The first directly in the wadi Bencheqcheq and the second, near the wadi Amiran in the region of Bouznika. "The cleaning operations cost 220,000 dirhams and we ask the authors of the pollution damages" [34].
Nowadays, there is a real gap between multinationals whose number remains limited and local businesses which are likely to be more numerous. Multinationals with significant resources are more compliant with safety standards for the transport of dangerous products and substances. Local operators, on the other hand, are relatively less sensitive to the importance of these standards. But, we still lack application texts. In the absence of these texts, professionals do not apply fortiori the regulatory provisions. By contrast, multinationals apply the standards of their parent companies while local companies do not apply the regulations. The change in this situation that threatens to give rise to a disaster at any time in the event of an accident requires a real awareness on the part of professionals and decision-makers.

\section{Conclusion}

This study presents the results of a survey on logistic choices related to HMs in Morocco. it focused on the determination of the nature of these HMs, in terms of classes of materials transported, frequency of supply and shipment, etc, and then identified the most used organizational security practices by Moroccan companies.

This study undertakes to determine the situation of hazardous materials in Morocco, we tried to give an analytical and holistic analysis for the whole transport logistic chain of these HMs.

Organizational and technical security measures need to improve through the introduction of a culture of safety throughout the HM chain of shippers, handlers, carriers and consignees of HMs, who must therefore receive training adapted to their field of activity and their level of responsibility especially for classes (classes 3, 2 and 8 ) as well as the high presence in the Moroccan industry sector and which have the highest risk in case of accident.

The results obtained in this research can help the interests involved (authorities, professionals and companies) for strategic and operational planning of the transport chain of dangerous products in Morocco.

The exploratory research we have conducted can pave the way for a wide variety of development perspectives. It might be interesting to extend this survey to the kingdom as a whole in order to highlight possible discrepancies in the use of organizational security practices.

Among other things, the possibility of developing a guide to good practices for carriers to inform them of the practices they can put in place to reduce their risk, or the possibility of making many recommendations to different ministries in relation to the training, the use of equipment, accident register policies, or even mount communication campaigns to raise awareness of the risks of multi-client carriers and multiple loading / unloading operations.

\section{Conflict of Interest}

The authors declare no conflict of interest.

\section{Acknowledgment}

The authors thank all the companies and people who participated in this work for their great support and valuable cooperation. 


\section{References}

[1] J. Yang, F. Li, J. Zhou, L. Zhang, L. Huang, and J. Bi, "A survey on hazardous materials accidents during road transport in China from 2000 to 2008," J. Hazard. Mater., vol. 184, no. 1-3, pp. 647-653, 2010.

[2] B. Y. Kara, "Designing a Road Network for Hazardous Materials Transportation," Transp. s, vol. 38, no. 2, pp. 188-196, 2004.

[3] J. Zhang, J. Hodgson, and E. Erkut, "Using GIS to assess the risks of hazardous materials transport in networks," Eur. J. Oper. Res., vol. 121, pp. 316-329, 2000.

[4] V. Verter and E. Erkut, "Hazardous materials logistics: An annotated bibliography," Oper. Res. Environ. Manag., pp. 221-267, 1996.

[5] Center for Chemical Process Safety (CCPS), Guidelines for chemical process quantitative risk analysis. Center for Chemical Process Safety of the American Institute of Chemical, 2000.

[6] A. Soussi et al., "Risk analysis for hazardous material transport by road: case study on Tangier-Tetouan region, Morocco," 018 13th Annu. Conf. Syst. Syst. Eng. (SoSE). IEEE, 2018., pp. 464-470, 2018.

[7] C. Bersani and C. Roncoli, "Real-time risk definition in the transport of dangerous goods by road," 2012 7th Int. Conf. Syst. Syst. Eng., 2012.

[8] C. Bersani, C., Minciardi, R., Tomasoni, A.M., Sacile, "Risk averse routing of hazardous materials with scheduled delays.," in Security and Environmental Sustainability of Multimodal Transport, NATO Science for Peace and Security Series C: Environmen, 2010, pp. 22-37.

[9] G. Rechkoska, R. Rechkoski, and M. Georgiska, "Transport of dangerous substances in the Republic of MAcdonia," Procedia - Soc. Behav. Sci., vol. 44, pp. 289-300, 2012.

[10] E. Erkut, "Hazardous Materials Transportation," in Handbook in $O R$ \& MS, vol. 14, no. 06, 2007, pp. 550-552.

[11] A. Oggero, R. M. Darbra, M. Mu, E. Planas, and J. Casal, "A survey of accidents occurring during the transport of hazardous substances by road and rail," J. Hazard. Mater., vol. 133, pp. 1-7, 2006.

[12] A. Conca, C. Ridella, and E. Sapori, "A Risk Assessment for Road Transportation of Dangerous Goods_A Routing Solution," Transp. Res. Procedia, vol. 14, pp. 2890-2899, 2016.

[13] R. M. Darbra, A. Palacios, and J. Casal, "Domino effect in chemical accidents : Main features and accident sequences," J. Hazard. Mater., vol. 183, no. 1-3, pp. 565-573, 2010.

[14] X. Huang, X. Wang, J. Pei, and M. Xu, "Risk assessment of the areas along the highway due to hazardous material transportation accidents," Nat. Hazards, vol. 93, no. 3, pp. 1181-1202, 2018.

[15] B. Fabiano and F. Currò, "From a survey on accidents in the downstream oil industry to the development of a detailed near-miss reporting system," Process Saf. Environ. Prot., vol. 90, no. 5, pp. 357-367, 2012.

[16] J. Planas-Cuchi, E., Montiel, H., \& Casal, "A survey of the origin, type and consequences of fire accidents in process plants and in the transportation of hazardous materials.," Process Saf. Environ. Prot., vol. 75, no. 1, pp. 3-8, 1997.

[17] J. Vilchez, J. A., Sevilla, S., Montiel, H., \& Casal, "Historical analysis of accidents in chemical plants and in the transportation of hazardous materials," J. Loss Prev. Process Ind., vol. 8, no. 2, pp. 87-96, 1995.

[18] G. F. List, P. B. Mirchandani, M. A. Turnquist, and K. G. Zografos, "Modeling and Analysis for Hazardous Materials Transportation: Risk Analysis, Routing / Scheduling and Facility Location," Transp. Sci., vol. 25, no. 2, pp. 100-114, 1991.

[19] M. Leroux, N. De Marcellis-warin, and M. Trépanier, "Safety management in hazardous materials logistics," Transp. Lett., pp. 13-25, 2010.

[20] M. Peignier, I., Leroux, M. H., de Marcellis-Warin, N., \& Trépanier, "Organizational safety practices of hazardous materials carriers Organizational safety practices of hazardous materials carriers," Transp. Lett., vol. 3, no. 3, pp. 149-159, 2011.

[21] X. Shen, Y. Yan, X. Li, C. Xie, and Lihua Wang, "Analysis on Tank Truck Accidents Involved in Road Hazardous Materials Transportation in China Analysis on Tank Truck Accidents Involved in Road Hazardous Materials Transportation in China," Traffic Inj. Prev., vol. 15, pp. 762-768, 2014.

[22] A. Ditta, O. Figueroa, G. Galindo, and R. yie-pinedo, "A review on research in transportation of hazardous materials," Socioecon. Plann. Sci., 2018.

[23] K. Van Raemdonck, C. Macharis, and O. Mairesse, "Risk analysis system for the transport of hazardous materials," J. Safety Res., vol. 45, pp. 55-63, 2013.

[24] M. Verma, "Railroad transportation of dangerous goods: A conditional exposure approach to minimize transport risk," Transp. Res. Part C, vol. 19, no. 5, pp. 790-802, 2011.

[25] E. Erkut and A. Ingolfsson, "Transport risk models for hazardous materials : revisited," Oper. Res. Lett., vol. 33, no. 1, pp. 81-89, 2005.

[26] IMIST (Institut Marocain de l'Information Scientifique et Technique), "Bulletin d'Information Technologique Chimie / Parachimie," Maroc, 2012.

[27] M. T. et I. P. Nathalie de Marcellis-Warin, Stratégies logistiques et matières dangereuses. 2013.

[28] B. EL MAITIA, "memoireonline," l'Organisation et le Financement des Marchés Publics au Maroc, 2008. [Online]. Available: https://www.memoireonline.com/05/08/1118/m_organisation-etfinancement-marches-publicsmaroc28.html?fbclid=IwAR2bh7atVh62Oz8fCSd8RiZeXMPMwcTcJCHY ZO-uqjiR8BHHSnBlZF_Ik1w.

[29] TMSA, "Tangier Med Special Agency," 2017. [Online]. Available: www.tmsa.ma/en.

[30] Gouvernment of Morocco, "Dahir n 1-11-37 du 29 joumada II 1432 (2 juin 2011) portant promulgation de la loi $n^{\circ} 30-05$ relative au transport par route de marchandises dangereuses." Bulletin officiel, Morocco, 2011.

[31] HCP (Haut Commisariat du Plan, Morocco), "Situation économique nationale 2018," 2018.

[32] Ministry of Economy, Morocco, "Le secteur de transport des marchandises : Contraintes et voies de réformes," 2013.

[33] Moroccan government, "Dahir n 1-01-223 du 10 joumada II 1422 (30 août 2001) portant publication de la Convention relative aux transports internationaux ferroviaires (COTIF), faite à Berne le 9 mai 1980." Bulletin officiel, pp. 468-541, 2002.

[34] Hassan EL ARIF, "Réforme du transport L'anarchie continue pour les matières dangereuses," $2014 . \quad$ [Online]. Available: https://www.leconomiste.com/article/917230-r-forme-du-transportlanarchie-continue-pour-les-mati-res-dangereuses. [Accessed: 06-Nov-2018]. 